\title{
A COMPREHENSIVE CONSTRUCTION OF HYDROGEN-HYDROGEN-OXYGEN (HHO) CELL AS RENEWABLE ENERGY STORAGE
}

\author{
Hesham M. Enshasy ${ }^{1}$, Qasem Abu Al-Haija ${ }^{2}$, Hasan Al-Amri, \\ Mohamed Al-Nashri, , Sultan Al-Muhaisen ${ }^{1}$, Mashhour Al-Tarayrah ${ }^{1}$ \\ ${ }^{1}$ King Faisal University, Department of Electrical Engineering, College of Engineering, Al-Ahsa, Saudi Arabia \\ ${ }^{2}$ Tennessee State University, Computer and Information Systems Engineering Department, Nashville, TN, USA \\ Email : \{qabualha@my.tnstate.edu\}
}

\begin{abstract}
In this paper, we propose a comprehensive design of HHO generation cell of the brown gas using three different design models, namely: parallel plates design for $\mathrm{HHO}$ cell, cylindrical tubes design for $\mathrm{HHO}$ cell, and spiral plates design for $\mathrm{HHO}$ cell. Extensive experimental results for the plate's parameters such as resistance, inductance and capacitance are proposed to get more insight into the proposed designs. The simulation data showed that minimizing the voltage at least to be $1.23 \mathrm{~V}$, will increase the effective current, hence improving the efficiency. On the other hand, shaping the input signal to the energy generation system, will lead to stabilizing the temperature and reduce the power loses.
\end{abstract}

Key Words : Clean Energy Storage, Current, Efficiency, Electrolysis, Energy, HHO Cells, Photovoltaic, Electricity Storage.

\section{Introduction}

Generally, energy consumptionis usually defined as the amount of energy or power used by individuals, industries, and countries. In the last decades, the annual world energy consumption increased rapidly for the last two decades which causes a rapid increase in environmental pollution thus push up the global warming to be a serious threat to our earth. Figure 1 showsthe world's energy consumption where the global primary energy consumption grew strongly in 2017, led by natural gas and renewables, with coal's share of the energy mix continuing to decline [1]. To reduce the pollution associated with power generation and storing, many efficient solutions that will reduce pollution to maintain safe environment for us and generations to come. One possible contemporary solution is the utilization of renewable energy such as the use of Hydrogen-Hydrogen Oxygen (HHO)cells which is considered as clean and relatively non-harmful source of energy [2].

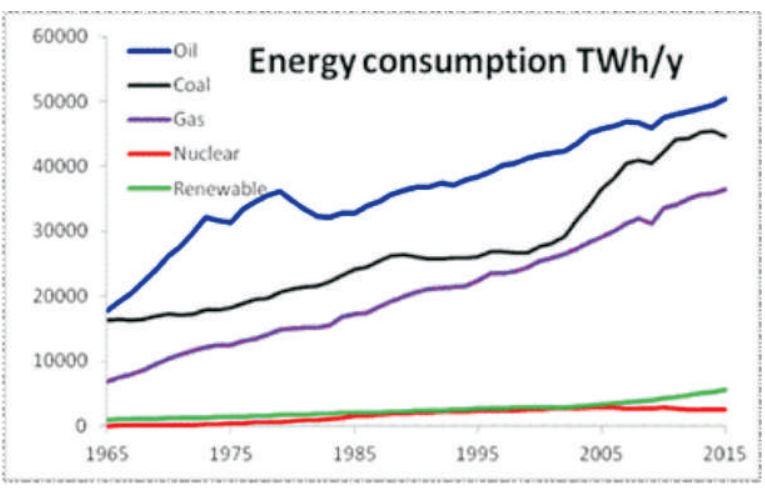

Fig.1 : The world's energy consumption (2015 data)[1].
Hydrogen-Hydrogen Oxygen (HHO) cells [3] are newly developed innovative solution to store energy with no harm effects for any of the beings on earth. HHO generation cells are introduced to be a green alternative energy storage source because of its advantages, which have overcome the environment pollution and global worming issues. $\mathrm{HHO}$ generation cell is environmentally friendly because the hydrogen burns completely without creating pollutants, toxic fumes, or public nuisance. Therefore, significant number of researches and experimental projects are being conducted around the world to optimize the exploitation of renewable energy using HHO Cells. For instance, M. Streblau, et. al [4] studied the operationof Hydrogen-Hydrogen-Oxygen (HHO) cells by varying the electrolyte parameters, concentration and temperature and monitoring the amount of gas produced per unit time compared to the electricity input. Theirexperimental results showed that energy processing time is exponentially proportional with the concentration of the electrolyte and thus the determination of the efficiency of the cell at higher temperatures by MMW is limited by the inability to account the amount of water vapor contained in the generated gas mixture. While R.M. Ahmad et.al. [5] proposed an on-board dry-cell HHO generation unit powered from a local photovoltaic (PV) system with variable-step P\&O MPPT technique used to extractthe PV panel power with minimized power oscillations without degrading the convergence time and thus the generated Hydrogen is then utilized to enhance the fuel consumption of a diesel engine.

Another noticeable work has been proposed in [6] where the authors presented a new design to generate hydrogen at constant rate to the $\mathrm{HHO}$ cells along with a constant 
current to run $\mathrm{HHO}$ controlled by the pulse width modulation (PWM) methodand the metal-oxidesemiconductor field effect transistors (MOSFET) of embedded system. As a result, they concluded that the use of $\mathrm{HHO}$ is more recommended concerned green environment and can be adopted for different cubic centimeter (cc) vehicles. Similarly, E. G. Chinchilla [7] studied the behavior of an internal combustion engine of a vehicle using oxyhydrogen (HHO) as a supplementary fuel using four stages: the first stage includes the theoretical and analysis of experiments of adding oxyhydrogen in the internal combustion engine which results instability of engine speed, the second stage consists of designing a controller based on fuzzy logic that results in increasing the fuel efficiency, the third stage related to the controller implementation in the vehicle, and the fourth stage consists of methods to verify and validate the data. The versification results showed that the adoption of HHO cells has increased the vehicle's fuel efficiency and enhanced the engine performance at different performed driving conditions without sacrificing engine power and torque.

Also,contributors of [8] studied the rate of oxy hydrogen gas generation (RNG) and the consumption of related energy (EC) using Taguchi's design and Regression model at different levels of selected factors. Accordingly, they developed and solved the optimization problems to maximize the RGN and minimize the $\mathrm{EC}$ which showed that RGN and its associated EC affected by the current more than other factors whereas the temperature and pressure factors have a slight effect. However, the pressure factors showed a negative effect on the process of oxy hydrogen gas generation. Moreover, M. M. Kassaby et. Al., [9] evaluated the effect of hydroxyl gas $\mathrm{HHO}$ on the emission and performance of a Skoda Felicia $1.3 \mathrm{GLXi}$ engines. They mixed HHO gas with a fresh air in the intake manifold. They found that $\mathrm{HHO}$ cells can be integrated with the existing engine systems in which mixing HHO gas with air/fuel has increased the engine thermal efficiency by $10 \%$ and reduced the consumption of fuel by $34 \%$. Furthermore, A. Al-Rousan [10] proposed a fuel cell design for $\mathrm{HHO}$ gas generation and applied his design by entering the generated $\mathrm{HHO}$ gas into the air before entering the carburetor of a Honda G 200 engine. He founds that combustion efficiency has been improved when using $\mathrm{HHO}$ in gasoline engines which resulted in reducing fuel consumption and thus decreasing pollution. Finally, authors of [11] studied the process of producing HHO gas using electrolysis process of different electrolytes

\section{Proposed Hardware Design}

Unlike traditional battery, Hydrogen-Hydrogen Oxygen (HHO) cells are newly developed innovative solution to store energy with no harm effects for any of the beings on earth. Table 1 shows a comparison between HHO cell and battery from different aspects.
Table 1

Comparison Between HHO Cell and Battery from Different Aspects.

\begin{tabular}{|c|c|c|}
\hline & HHO cell & Battery \\
\hline Availability & $\begin{array}{l}\text { Limited, in research } \\
\text { phase }\end{array}$ & Available \\
\hline $\begin{array}{l}\text { Durability } \\
\text { Component }\end{array}$ & $\begin{array}{l}\text { Long time }>20 \text { years } \\
\text { Stainless steel }\end{array}$ & $\begin{array}{l}\text { Usually 2-5 years } \\
\text { Chemical substance i.e. } \\
\text { Lead, sulfuric acid, } \\
\text { lithium...etc. }\end{array}$ \\
\hline $\begin{array}{l}\text { Environmental } \\
\text { impact } \\
\text { Cost }\end{array}$ & $\begin{array}{l}\text { No bad impact } \\
\text { Less expensive for } \\
\text { short and long term }\end{array}$ & $\begin{array}{l}\text { Cause pollution, Global } \\
\text { warming } \\
\text { Expensive for short and } \\
\text { long term }\end{array}$ \\
\hline $\begin{array}{l}\text { Storage capacity } \\
\text { System waste }\end{array}$ & $\begin{array}{l}\text { Small storage space } \\
\text { Environmentally } \\
\text { friendly distilled } \\
\text { water. }\end{array}$ & $\begin{array}{l}\text { Large storage space } \\
\text { Environmentally } \\
\text { harmful gas emission }\end{array}$ \\
\hline $\begin{array}{l}\text { Scalability } \\
\text { Efficiency } \\
\text { Cost of large } \\
\text { scale }\end{array}$ & $\begin{array}{l}\text { Scalable } \\
\text {--- } \\
\text { Very low compared } \\
\text { to batteries }\end{array}$ & $\begin{array}{l}\text { Scalable } \\
\text { Below 70\% } \\
\text { Very high }\end{array}$ \\
\hline
\end{tabular}

In terms of availability, battery in the market is more available than the $\mathrm{HHO}$ cell due to the common think that the battery is the only energy storage element introduced to the world. Another aspect is the durability of the system; HHO cell is more durable because it constructed from special type of stainless steel (Type 304) that can last for more than twenty years without rust [12] while the batteries approximately last for 2-5 years depending on its fabrication material before they become decompose and need for recycling. Regarding the environmental impact, $\mathrm{HHO}$ cells considered as a green energy element that no bad effect on the environment as its wastage is distilled water and can be used for drinking whereas the batteries cause pollution because of the leakage of chemical substance or gases emission emerging from the batteries that may cause harm for people, animals and earth. Moreover, although the construction cost of small scale HHO is more expensive than battery as it still in the research phase, large scale facilities are much less cost than large scale batteries storage facilities. Also, large scale facilities of $\mathrm{HHO}$ cells provides much higher life time and larger storage capacity with no harmful effect as well as no recycling stage is needed in the. Both technologies are scalable since the size of the storage element will vary depends on the application type. The efficiency for the battery was found to be around no more $70 \%$ [13] whereas the efficiency of HHO cell could not be determined because $\mathrm{HHO}$ cells are in research phase and it's an application dependent technology. It's expected to be much lower and as farther research development expected to increase. 

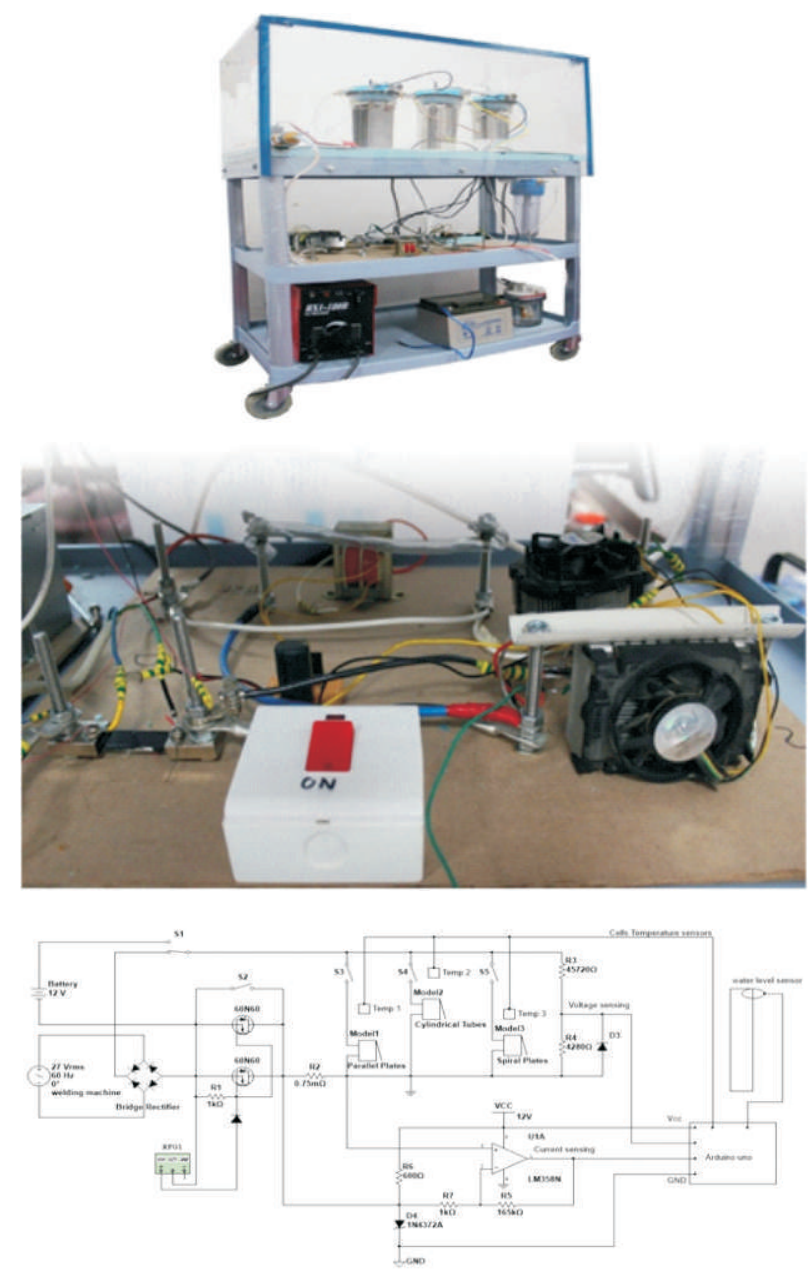

Fig. 2. (a) Overall System (b) HHO System implemented Circuit (c) HHO System Circuit.

The overall system view is provided in Figure 2 which shows the practical overview for the proposed HHO cells system along with the comprehensive integrated circuit design of HHO generation cells. Once the power is delivered to the cells, electrical current will flow in the water via the stainless steel. As a result, the water will start to be converted to $\mathrm{HHO}$ gas due to electrolysis. After that, the gas will flow through the piping system to the bubbler which is already filled with water to act as insulation. Out of the bubbler, the gas will flow to a container filled with water. The coming gas will be stored in this course, and it will displace the water into a level tube to calculate the gas quantity via the displaced water.

\subsection{Supplies and Shaping circuits.}

There are two types of power supplies have been used to provide the system with needed power. Alternating power out from AC Welding machine is used to provide DC power due to its capability of providing over 180 Ampere. In addition, DC power is provided from (LP-12-38 Battery), which can give about $12 \mathrm{~V}$ and $38 \mathrm{~A} / \mathrm{h}$.
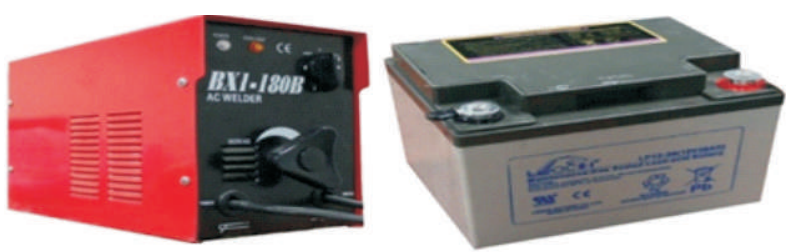

Fig. 4 : (a) AC Welder Machine (b) 12V DC Battery

Fig. 4 shows the two main power sources which have been used to deliver the desired power to the cells for the electrolysis process. Fig. 4(a) shows the AC/DC power supply which used to charge the battery and to supply the circuit with direct and alternating voltage and current. The power supply can give up to $30 \mathrm{~V}$ and $5 \mathrm{~A}$. To control the duty of PWM, a function generator with the capability to vary the duty cycle is required. The function generator provides the freedom to tune the duty cycle to the desired to achieve the required PWM.Also, Fig.5(b) shows the function generator which used to generate different type of signal with different rang of frequencies for the circuit to shape the DC voltage and produce PWM.Also, analyzing the circuit is an essential technique to verify signal processing through the circuit. Therefore, digital oscilloscope is used evaluate the signal. Finally, Fig. 5 (c) shows the digital oscilloscope which used to sketch the output wave form. Also, it uses for analyzing the output to compare the result with each other.

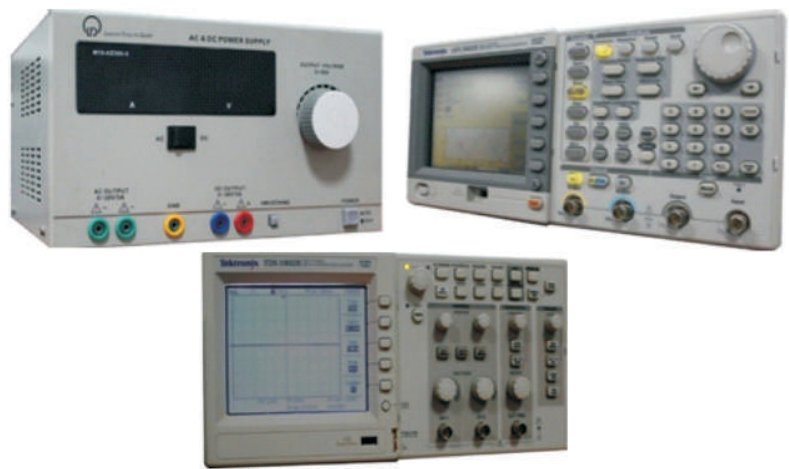

Fig. 5 : (a) DC/AC Power Supply (b) Function GeneratorModel AFG 3022B Tektronix (c) Digital Oscilloscope

Also, full wave Rectifier Bridge is one of the $\mathrm{AC} / \mathrm{DC}$ Converters in which a DC output is targeted from AC input through the Bridge of diodes. Which can handle up to 50Amp. Fig. 6 (a) and (b) shows thebridge rectifier units and bridge rectifier circuit respectively.Chopping the signal is one technique that will be used to generate Pulse Width Modulation signal PWM to investigate the response of such input power. Fig.6 (c) showsthe switching circuit that is used to generate PWM signal. The PWM signal is provided as input power for the $\mathrm{HHO}$ cells. The HHO systems consume a lot of current and the switching MOSFET (60N60) cannot handle this current; therefore, we added two MOSFET with heat sinkfor cooling. 

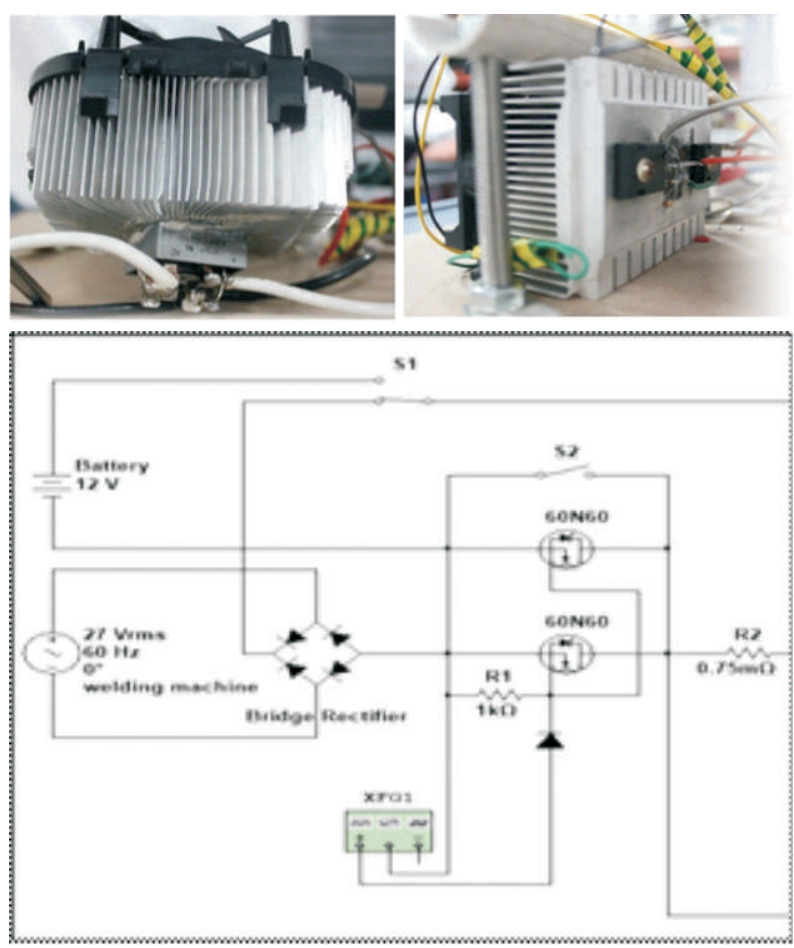

Fig. 6 : (a) Bridge Rectifier (b)The supplies and chopping circuit (c) the switching circuit to generate PWM signal

\subsection{Power Measurement Circuitry.}

To calculate the electric power for each cell, it is needed to measure the voltage across the electrodes of the cell and the current entered to the cell. The voltage for each cell is simply measured across the cell's electrodes. Since that the current is pass through the cells by a small resistor. Fig.7 (a) shows the current and voltage measuring circuit.Also, a small resistor $750 \mu \Omega$ is used to calculate the current entered to the cell. But since the drop voltage across this resistor is too low, the ARDUINO (microcontroller) cannot read it. Fig. 7 (b) shows the resistor which used to calculate the series current.
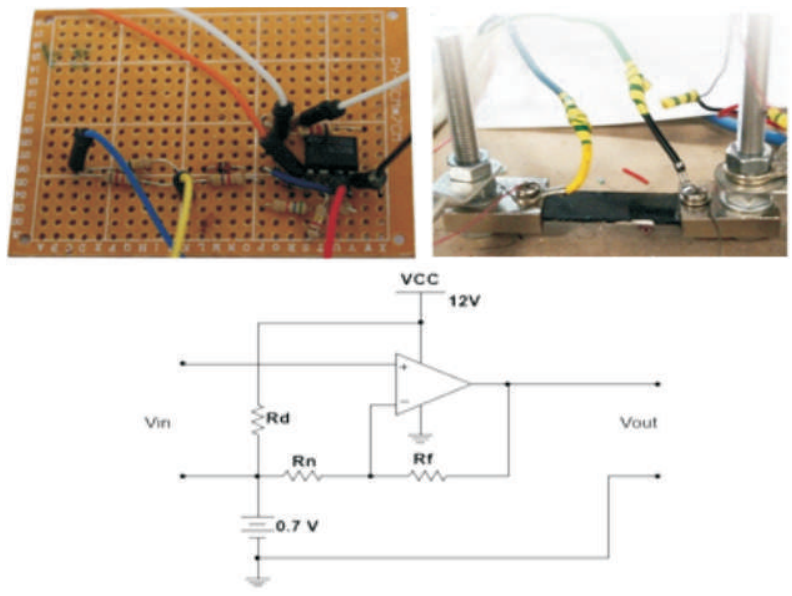

Fig.7 : (a) Current and voltage Measuring Circuit (b)

$750 \mu \Omega$ Resistor (c) Non-inverting Op-Amp circuit
The maximum Analog Digital Converter (ADC) resolution of ARDUINO UNO is 10bit, which equal to 1023 steps and the supply voltage to Arduino is $5 \mathrm{~V}$. Therefore, the minimum current that can be read by ARDUINO directly can be measured as follows:

$$
\begin{gathered}
V_{\min }=\frac{(\min \text { step })(\max \text { voltage })}{\text { total step }}=\frac{(1)(5 \mathrm{~V})}{1023}=4.9 \mathrm{mV} \\
I_{\min }=\frac{V_{\min }}{R}=\frac{4.9 \mathrm{mV}}{0.75 \mathrm{~m} \Omega}=6.53 \mathrm{~A}
\end{gathered}
$$

Such current values (i.e.6.53A) is considered as huge step and very bad resolution. Therefore, the amplifier must be used to amplifying the signal of the current and increase the resolution.Thus, we have used Non-Inverting Opamp. The Non-Inverting Op-Amp circuit is given in Fig.7(c). Since Non-Inverting Op-amp with single supply is used, we had to shift up the input signal to avoid the clipping as follows:

$$
V_{\text {out }}=V_{\text {in }} A+0.7 \rightarrow V_{\text {out }}=\frac{R_{f}}{R_{\text {in }}}+1
$$

Let's assume that the maximum current that will flow into the system is $40 \mathrm{~A}$, which will generate a drop voltage across the current resister $(0.75 \mathrm{~m} \Omega)$ as following :

$V_{\max }=R I_{\max }=(0.75 \mathrm{~m} \Omega) \quad(40 \mathrm{~A})=30 \mathrm{mV}$ Therefore, the maximum voltage across the resister will be $30 \mathrm{mV}$ when the current is $40 \mathrm{Amp}$. When the $V_{\text {in }}=V_{\text {max }}$ the $V_{\text {out }}$ must be equal to $5 \mathrm{~V}$.Now, by substituting the values in equ.1 assuming that $R_{i n}=1.2 \mathrm{k} \Omega$, we get the following:

$$
\begin{gathered}
5 V=30 m V A+0.7 \rightarrow A=\frac{5-0.7}{0.03}=143.3 \rightarrow \\
143.3=\frac{R_{f}}{1200}+1 \rightarrow R_{f}=(143.3-1) 1200=170.5 \mathrm{k} \Omega
\end{gathered}
$$

Finally, the minimum current that can be sensed by Arduino MCU after the amplificationis:

$$
I_{\min }=\frac{V_{\min }}{R A+0.7}=\frac{4.9 m V}{(0.75 m \Omega)(143.3)+0.7}=6.07 m A
$$

The one step of accuracy of measuring the current has been increased from $6.53 \mathrm{~A}$ to $6.07 \mathrm{~mA}$

\subsection{Temperature MeasurementsCircuitry}

For each cell there is a temperature Sensor (DS18B20) is used to measure the internal temperature of the cell. This sensor is waterproof which has been used inside the container to increase the accuracy of temperature sensing. Fig. 8 shows the used temperature sensor. 


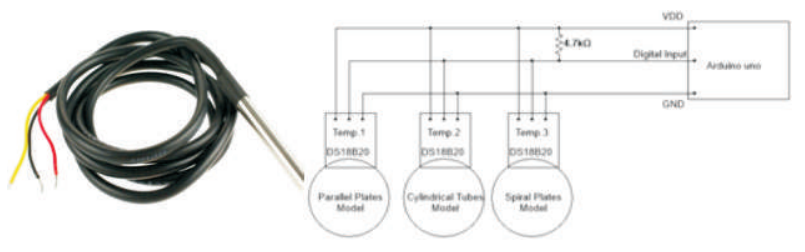

Fig. 8 : Temperature Sensor and Tempreture Sensor Circuit

\subsection{Control Switches and Valves}

The three cells are connected in parallel, and for each time only one cell is working. Thereby, the circuit will be connected in-series through one cell at a time to ensure that the current which measure across the resistor is the one which entered the cell.Also, for each cell, there is a valve to control the flow of $\mathrm{HHO}$ gas out of the cell to the bubbler, also to increase the flexibility especially when taken the measurement. Fig.9 shows the three ON/OFF switches that control the system and the valves that control the gas flow for each cell.
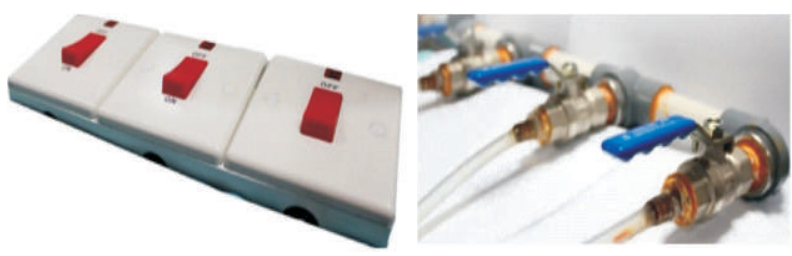

Fig. 9 : Switches and Valves

\subsection{Safety Bubbler}

As a safety precaution, a bubbler has been installed to the pipe out of the cells to isolate the produce HHO gas from the cells in case of emergency.
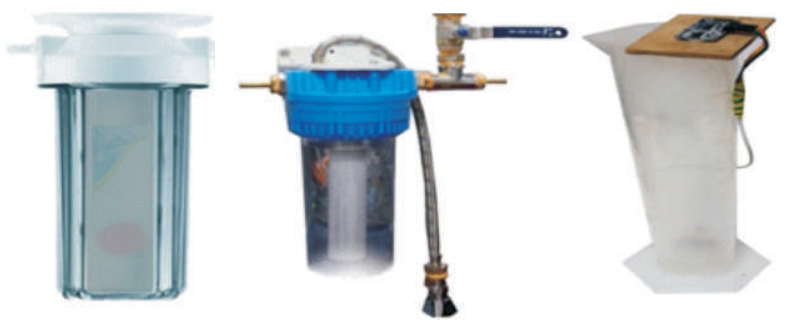

Fig. 10 : (a) Typical Bubbler Unit (b) Multipurpose bubbler Unit (c) Level tube to calculate the amount of gas by ultrasonic sensor

\subsection{Actual Models for HHO cells}

Three designs have been fabricated to apply the proposed set of experiments targeting the optimum design. Fig. 11 shows (a) the front-view of the three fabricated cells of $\mathrm{HHO}$ cell together, (b) Parallel Plates model for HHO Cell, (C) Cylindrical tubes model for HHO Cell, and (d) Spiral Plates model for HHO Cell.

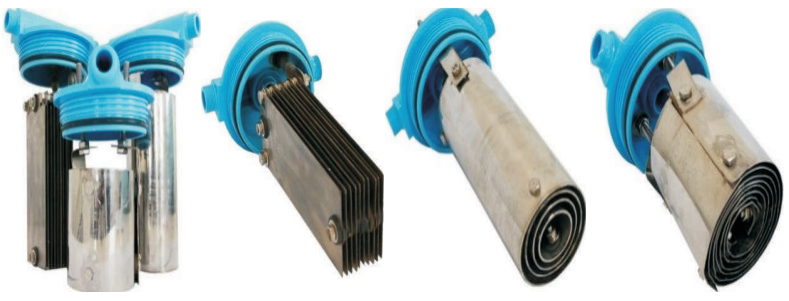

Fig.11.(a) Alltogother System models (b) Parallel Plates model (c) Cylindrical tubes model (d) Spiral Plates model.

Note that the crucial factor is the surface area as the aim of proposed design is to maintain an equivalent surface area for the three modelsto facilitate a faircomparison and benchmarking between the proposed models to find up the most efficient design. To keep the surface area fixed, it is necessary to choose the right number of plates and the distance between them based on the theoretical calculation. Note that all the models have been constructed from 304/304L stainless steel material with thickness of $0.5 \mathrm{~mm}$ since this type of stainless steel has a higher corrosion resistance and it is widely used because of the ease of shaping as it can be formed into various shapes [14]. However, each model has its own specifications as:

\subsection{The Parallel Plates Model}

This model built up by using ten parallel plate; five plates connected to represent the cathode (negative) and the other five plates representing the anode (positive). Those plates are held together from the top by the head of the container which used to do the electrolysis. Each one of this plate has a dimension of $18 \mathrm{~cm}$ length and $7 \mathrm{~cm}$ width and the distance between the plates is $5 \mathrm{~mm}$. Thus, the total surface area is equal to $1,260 \mathrm{~cm} 2$.

\subsection{Cylindrical Tubes Model}

This model is built up by using four cylinders; two cylinders connected to represent the cathode (negative) and the other two cylinders representing the anode (positive). Those cylinders are held together from the top by the head of the container which used to do the electrolysis. The cylinders have a dimension of $17.5 \mathrm{~cm}$ high and3.8, 5.1, $6.4 \& 7.6 \mathrm{~cm}$ 's (1.5", 2", 2.5" \&3")diameter and the distance between the cylinders is $5 \mathrm{~mm}$. Thus, the total surface area is equal to $1,260 \mathrm{~cm}^{2}$.

Spiral Plates Model: This model built up by using two twisted plates, one plate represents the cathode (negative) and the other plate representing the anode (positive). Those plates are held together from the top by the head of the container which used to do the electrolysis. Each one of this cylinder has a dimension of $126 \mathrm{cmlength}$ and $10 \mathrm{~cm}$ width and the distance between the plates is $5 \mathrm{~mm}$. Thus, the total surface area is equal to $1,260 \mathrm{~cm}^{2}$. 


\section{Unit Testing and System Integration}

The complete integrated circuit of the system is illustrated in Fig.12 (a). The control unit controls several processes at the same time and it controls the signal by high power switching to electrolyze the water. The electric valve controls the flow of water, when the Infrared Ray (IR) transducer detect that the level of water less than the set point (i.e. the pre-specified threshold). The power measuring unit calculates the average power if the power supply had been used; otherwise, it will calculate the apparent power. Thereafter, to ensure accurate verification and precise validation for system functionalities, we have conducted considerable number of experiments for each single design model to analyze the effectiveness of hydrogen oxygen gas production out of each cell.
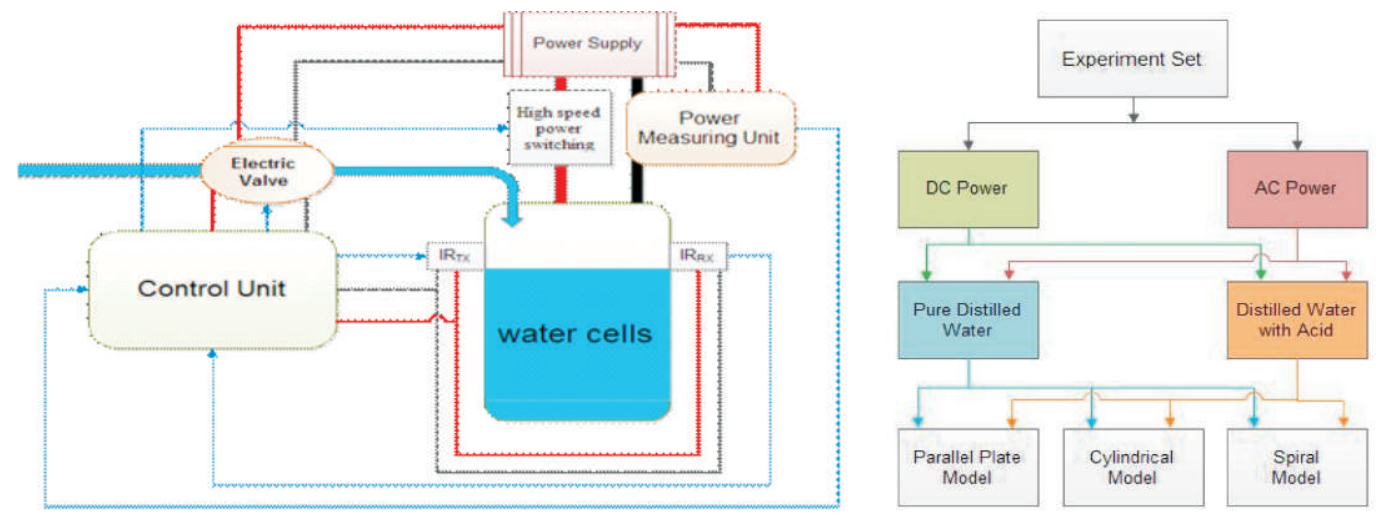

Fig. 12 : (a) The integrated circuit of the system (b) Experiment Set chart for each design of the three cells.

These experiment sets are categorized into two major categories: Experiments using DC power out from a battery and Experiments using DC power out from AC Welding Machine to supply high current. Also, we have used two types of water to investigate the efficient type of water,pure distilled water and distilled water with acid. Furthermore, two options are provided as an external catalyst for the electrolysis.Figure12 (b)shows the experiment set that will be applied for the three design cells: Parallel Plate, Cylindrical and Spiral. According to the figure, different power source is supplied: the battery is used to provide and maintain certain DC level, which is pure DC supplied from the battery while AC Welding Machine will be used to produce DC Power via full bridge diode. The supplied power (either from the battery or AC Welding Machine through full wave rectifier) is modulated using Pulse Width Modulation (PWM) for different Duty cycle such as 25\%, 50\% and $75 \%$ of the used AC power. The used frequency is $1 \mathrm{kHz}(25 \%, 50 \%$ and $75 \%$ of duty cycle), $10 \mathrm{kHz}(50 \%$ of duty cycle), $50 \mathrm{kHz}$ ( $50 \%$ of duty cycle) and $100 \mathrm{kHz}(50 \%$ of duty cycle). What distinguish the DC output of the battery from the DC output of the AC Welding Machine is that the output DC of the battery has no ripples while the other has ripples. Sulfuric acid $\left(\mathrm{H}_{2} \mathrm{SO}_{4}\right)$ is used to increase the conductivity of water to enhance the electrolysis process. In coming part, we will provide several figures that demonstrates the results of the steps of the experimental measurements. The summary of experimental results is given in Table I.We have plotted all results in the table via MATLAB to analyze and study the behavior of different relationships as shown in the set of Figures (12-29).

Table 2

Experimental Sets for The Three Models Using Two Types of Water and Two Different Voltage Sources

\begin{tabular}{|c|c|c|c|c|c|c|c|}
\hline \multicolumn{8}{|c|}{ Pure Distilled Water } \\
\hline \multirow{8}{*}{ 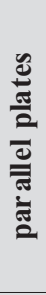 } & Voltage Type & Frequency/ Duty cycle & dtime (S) & dLevel (mL) & dT & Energy (kJ) & $\mathrm{dl} / \mathbf{E}$ \\
\hline & $\mathrm{DC}$ & & 641.70 & 113 & 1.5 & 4.8342506 & 23.374874 \\
\hline & \multirow{6}{*}{$\mathrm{AC}$} & $1 \mathrm{kHz} 25 \%$ & 818 & 6 & 0.06 & 1.3497 & 4.445432 \\
\hline & & $1 \mathrm{kHz} 50 \%$ & 303 & 15 & 0.12 & 1.212 & 12.37624 \\
\hline & & $1 \mathrm{kHz} 75 \%$ & 573 & 110 & 0.62 & 3.990945 & 27.56239 \\
\hline & & $10 \mathrm{kHz}$ & 151 & 20 & 0.13 & 1.812 & 11.03753 \\
\hline & & $50 \mathrm{kHz}$ & 1065 & 30 & 0.06 & 2.20455 & 13.60822 \\
\hline & & $100 \mathrm{kHz}$ & 781 & 15 & 0.06 & 1.8744 & 8.002561 \\
\hline \multirow{7}{*}{ 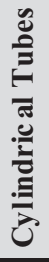 } & $\mathrm{DC}$ & & 991.32 & 103 & 0.81 & 4.752337 & 21.673547 \\
\hline & \multirow{6}{*}{$\mathrm{AC}$} & $1 \mathrm{khz} 25 \%$ & 2422 & 50 & 0.5 & 2.71264 & 18.43223 \\
\hline & & $1 \mathrm{khz} 50 \%$ & 3300 & 60 & 0.87 & 10.692 & 5.611672 \\
\hline & & $1 \mathrm{khz} 75 \%$ & 425 & 45 & 0.32 & 2.295 & 19.60784 \\
\hline & & $10 \mathrm{khz}$ & 593 & 15 & 0.25 & 2.73966 & 5.475132 \\
\hline & & $50 \mathrm{khz}$ & 423 & 10 & 0.13 & 1.312146 & 7.621103 \\
\hline & & $100 \mathrm{khz}$ & 655 & 10 & 0 & 0.8515 & 11.74398 \\
\hline
\end{tabular}




\begin{tabular}{|c|c|c|c|c|c|c|c|}
\hline \multirow{6}{*}{ 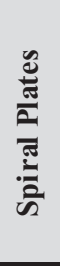 } & $\mathrm{DC}$ & $1 \mathrm{khz} 25 \%$ & $\begin{array}{l}1596.60 \\
1179\end{array}$ & $\begin{array}{l}105 \\
45\end{array}$ & $\begin{array}{l}1.75 \\
0.42\end{array}$ & $\begin{array}{l}6.568489 \\
2.5938\end{array}$ & $\begin{array}{l}15.985412 \\
17.34906\end{array}$ \\
\hline & \multirow{5}{*}{$\mathrm{AC}$} & $1 \mathrm{khz} 50 \%$ & 763 & 65 & 0.43 & 4.2728 & 15.21251 \\
\hline & & $1 \mathrm{khz} 75 \%$ & 349 & 44 & 0.44 & 3.26664 & 13.4695 \\
\hline & & $10 \mathrm{khz}$ & 871 & 55 & 0.63 & 4.638075 & 11.85837 \\
\hline & & $50 \mathrm{khz}$ & 366 & 15 & 0 & 1.61406 & 9.293335 \\
\hline & & $100 \mathrm{khz}$ & 400 & 20 & 0.19 & 2.56 & 7.8125 \\
\hline \multicolumn{8}{|c|}{ Distilled Water withAcid } \\
\hline \multirow{8}{*}{ 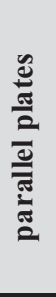 } & Voltage Type & Frequency/ Duty cycle & dtime (S) & dLevel (mL) & dT & Energy (kJ) & $\mathrm{dl} / \mathrm{E}$ \\
\hline & $\mathrm{DC}$ & & 19.00 & 90 & 0.75 & 6.0401 & 14.90041556 \\
\hline & \multirow{6}{*}{$\mathrm{AC}$} & $1 \mathrm{kHz} 25 \%$ & 48.26 & 45 & 0.25 & 1.455039 & 30.92701 \\
\hline & & $1 \mathrm{kHz} 50 \%$ & 38.66 & 70 & 0.37 & 2.711999 & 25.81122 \\
\hline & & $1 \mathrm{kHz} 75 \%$ & 40.78 & 87 & 0.32 & 5.187216 & 16.772 \\
\hline & & $10 \mathrm{kHz}$ & 44.21 & 35 & 0.19 & 1.570339 & 22.28818 \\
\hline & & $50 \mathrm{kHz}$ & 43.38 & 23 & 0.06 & 0.947419 & 24.27648 \\
\hline & & $100 \mathrm{kHz}$ & 50.85 & 23 & 0.37 & 1.043442 & 23.95917 \\
\hline \multirow{7}{*}{ 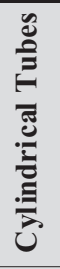 } & $\mathrm{DC}$ & & 11.66 & 40 & 0.69 & 2.936571 & 13.621329 \\
\hline & \multirow{6}{*}{$\mathrm{AC}$} & $1 \mathrm{khz} 25 \%$ & 47.66 & 28 & 0.44 & 1.388812 & 20.16111 \\
\hline & & $1 \mathrm{khz} 50 \%$ & 31.96 & 49 & 0.31 & 2.0774 & 23.58718 \\
\hline & & $1 \mathrm{khz} 75 \%$ & 20.18 & 43 & 0.25 & 2.233926 & 19.24862 \\
\hline & & $10 \mathrm{khz}$ & 43.83 & 35 & 0.25 & 1.35873 & 25.75935 \\
\hline & & $50 \mathrm{khz}$ & 35.55 & 20 & 0.06 & 0.95985 & 20.83659 \\
\hline & & $100 \mathrm{khz}$ & 32.48 & 20 & 0.06 & 0.672336 & 29.74703 \\
\hline \multirow{7}{*}{ 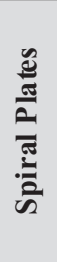 } & $\mathrm{DC}$ & & 15.05 & 95 & 0.81 & 5.5295205 & 17.180513 \\
\hline & \multirow{6}{*}{$\mathrm{AC}$} & 1khz 25\% & 53.8 & 70 & 0.31 & 2.276816 & 30.74469 \\
\hline & & $1 \mathrm{khz} 50 \%$ & 29.59 & 70 & 0.32 & 2.351221 & 29.77176 \\
\hline & & $1 \mathrm{khz} 75 \%$ & 22.21 & 65 & 0.22 & 2.92639 & 22.21167 \\
\hline & & $10 \mathrm{khz}$ & 39.96 & 55 & 0.06 & 2.06793 & 26.59664 \\
\hline & & $50 \mathrm{khz}$ & 23.64 & 20 & 0.03 & 0.612749 & 32.6398 \\
\hline & & $100 \mathrm{khz}$ & 26.05 & 20 & 0.02 & 0.608528 & 32.8662 \\
\hline
\end{tabular}

* Refer to The Appendix to see the test result from Oscilloscope device.

Fig.13 shows the relationship between the level of HHO per Energy with respect to frequency change. Its observed that the distilled water with acid generate more $\mathrm{HHO}$ gas by the same energy; on other said, the pure distilled water generates less $\mathrm{HHO}$ gas by the same energy at low frequencies. Moreover, the distilled water with acid is more affected by low frequency, since it has more conductivity than the pure distilled water.

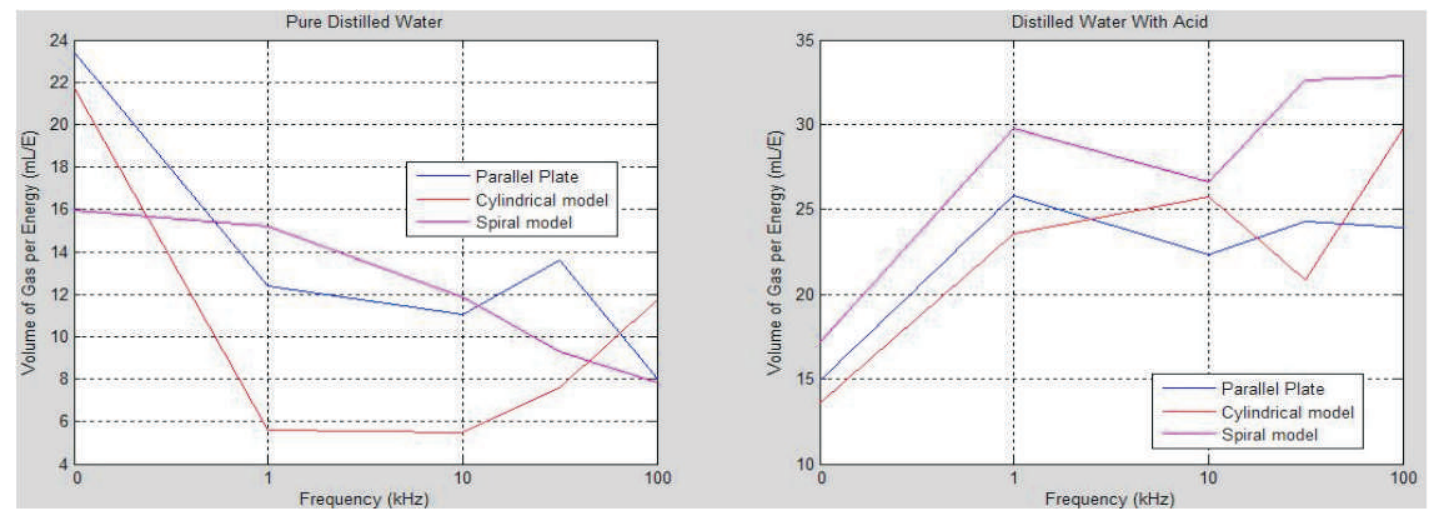

Fig. 13 : Level of HHO per Energy with Respect to Frequency.

Figure 14 shows the relationship between the volume of HHO per Energy with respect to three designs with acid and without. It can be observed that the applied DC voltage is almost efficient than AC voltage of pure distilled water for the three designs. However, the applied DC voltage has the least efficiency comparing with AC voltage of distilled water with acid for the three designs. 


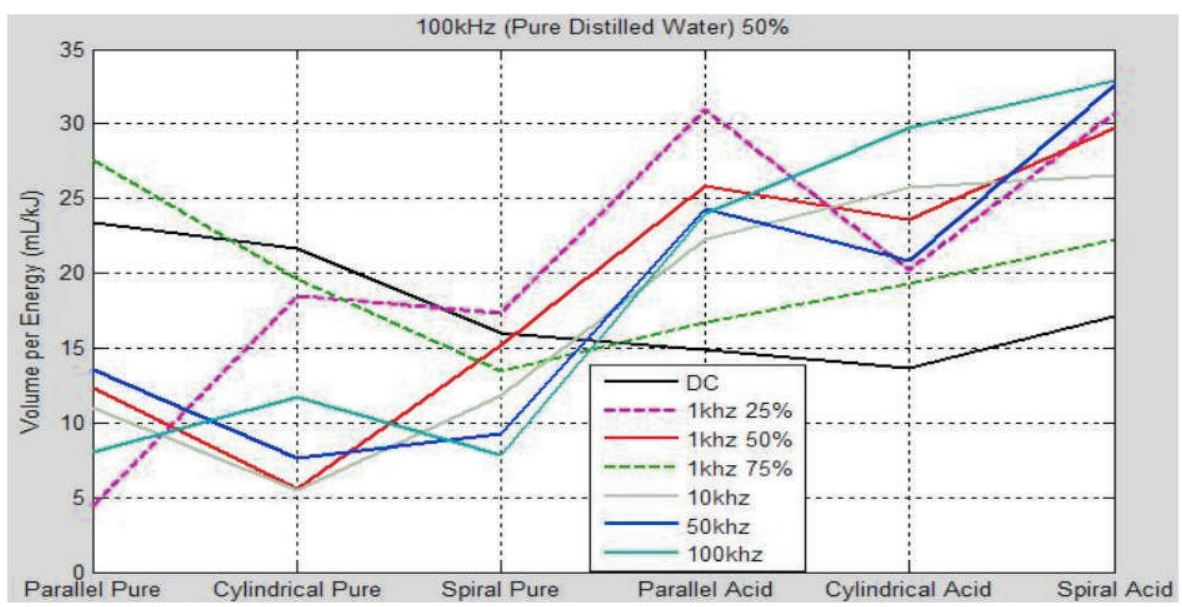

Fig. 14 : Relationship between the volumes of HHO per Energy for the three models
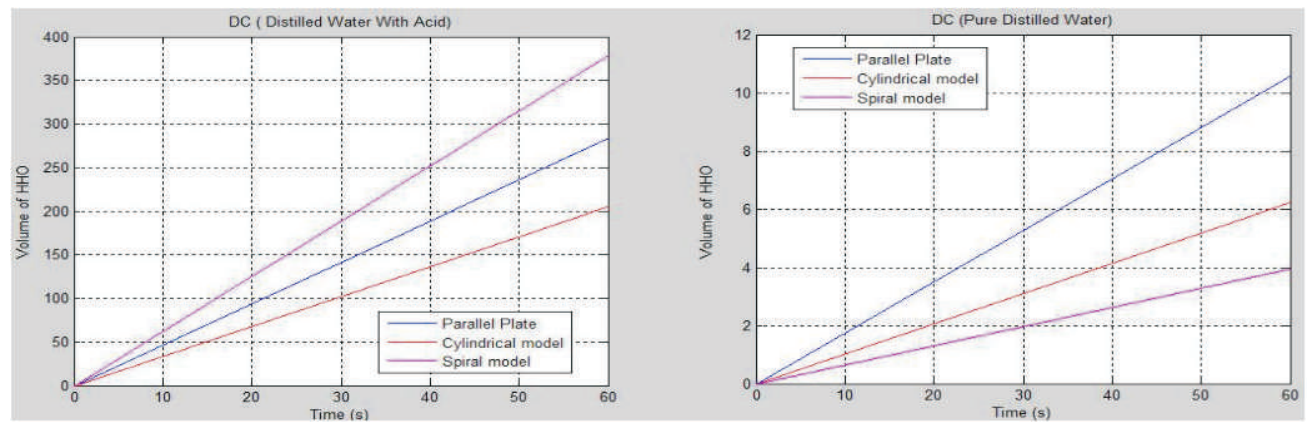

Fig. 15 : Volume of HHO with respect to Time for DC Power.
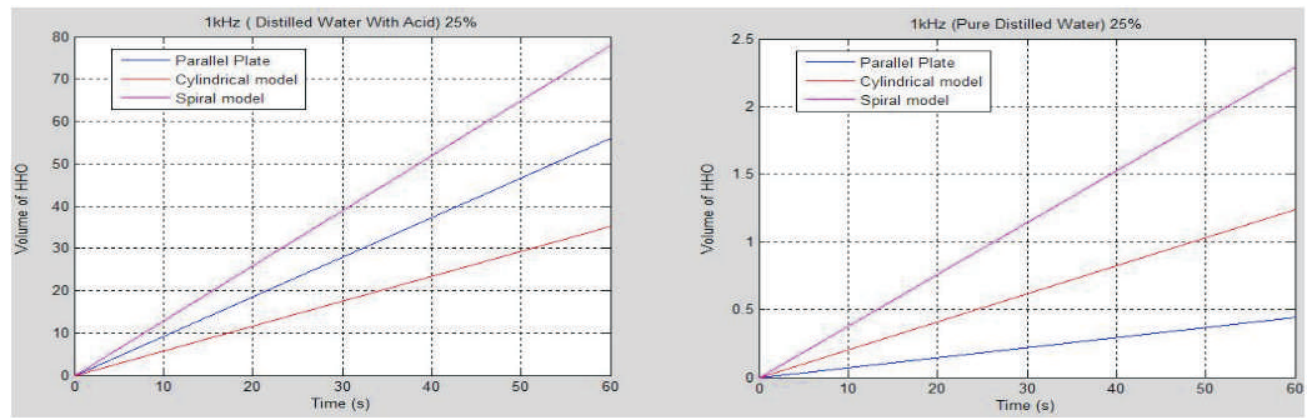

Fig. 16: Volume of HHO with Respect to Time for $1 \mathrm{kHz}$ PWM of 25\% Duty Cycle.
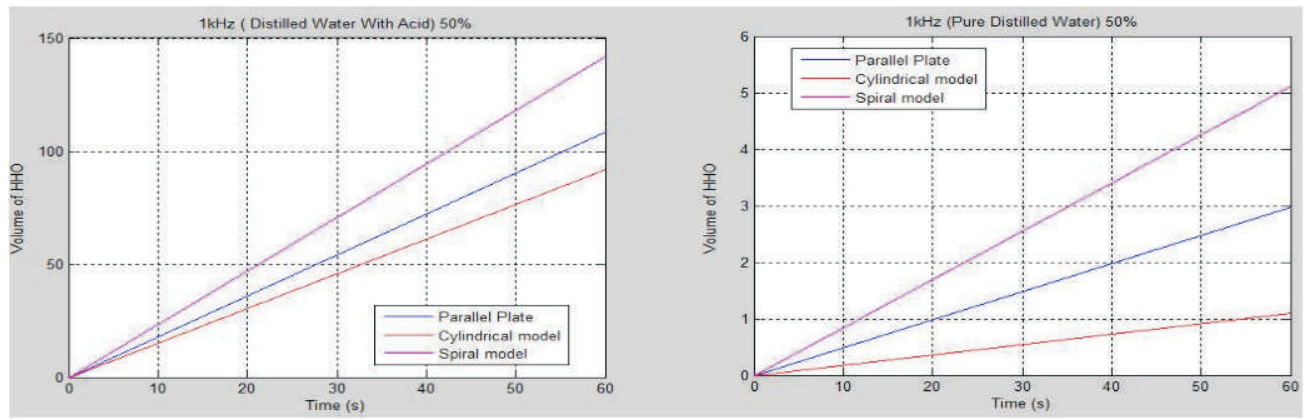

Fig. 17 : Volume of $\mathrm{HHO}$ with Respect to Time for $1 \mathrm{kHz}$ PWM of 50\% Duty Cycle. 

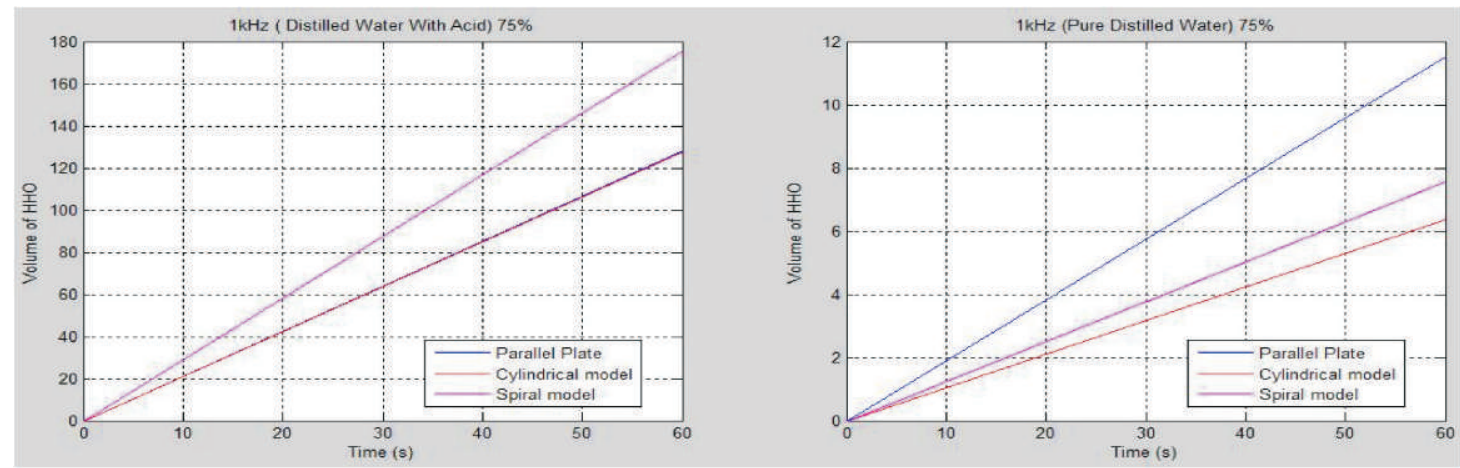

Fig. 18 : Volume of HHO with Respect to Time for $1 \mathrm{kHz}$ PWM of $75 \%$ Duty Cycle.
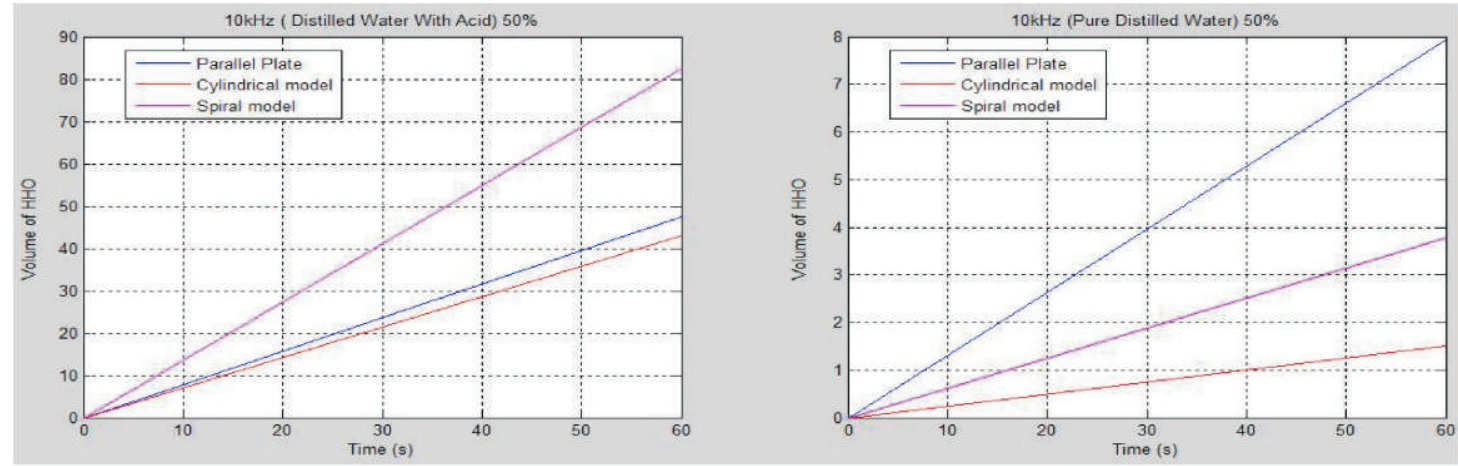

Fig. 19 : Volume of HHO with Respect to Time for 10kHz PWM of 50\% Duty Cycle.
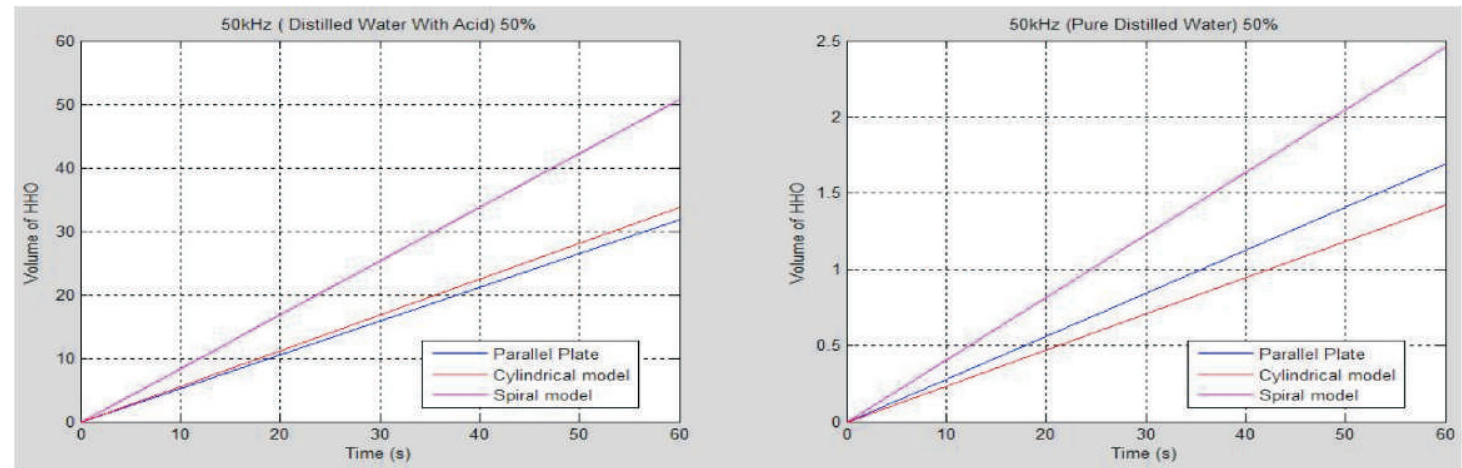

Fig. 20 : Volume of HHO with Respect to Time for 50kHz PWM of 50\% Duty Cycle.
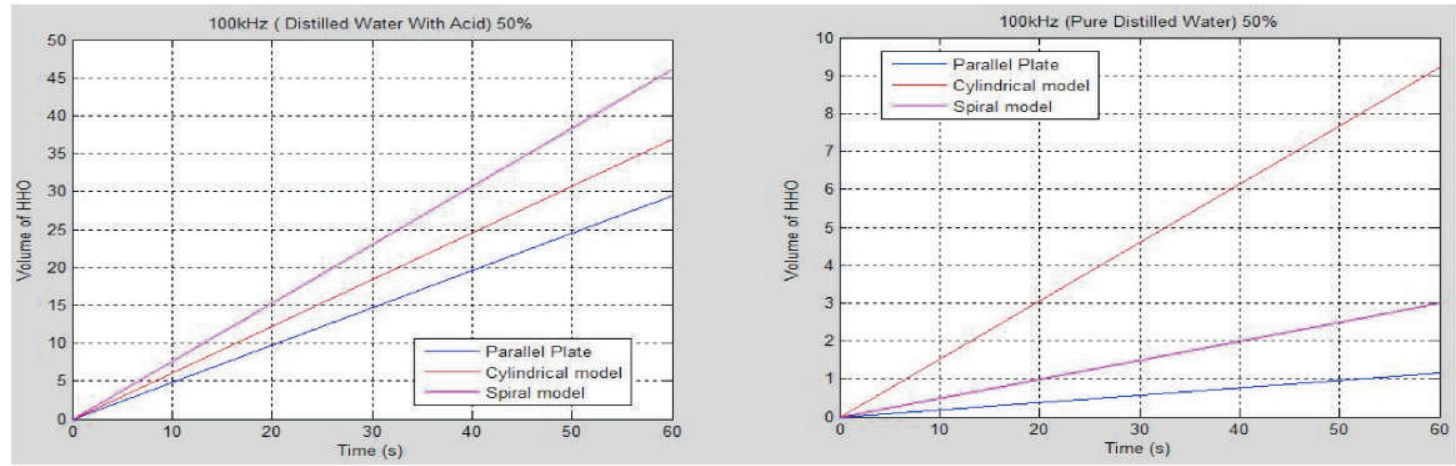

Fig. 21 : Volume of HHO with Respect to Time for 100kHz PWM of 50\% Duty Cycle. 

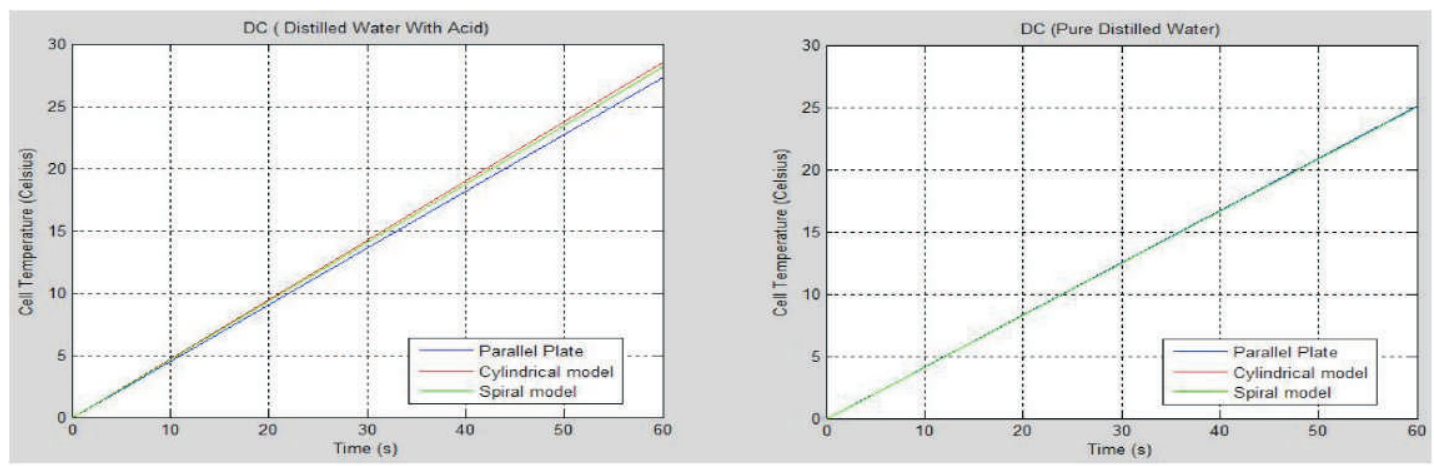

Fig. 22 : Cell Temperature with Respect to Time for DC Power.
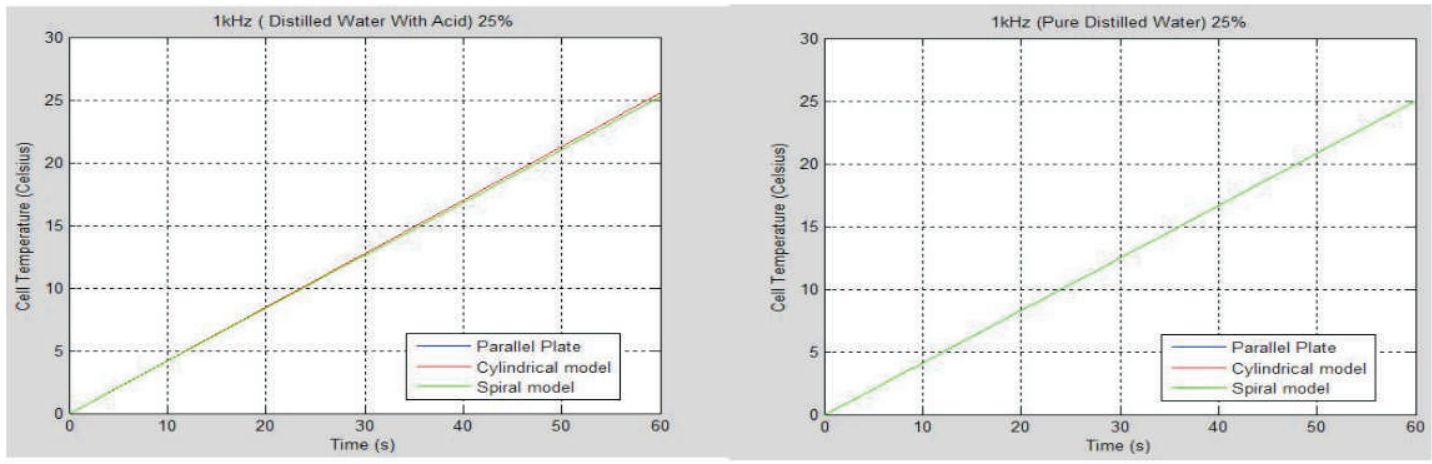

Fig. 23 : Cell Temperature with Respect to Time for $1 \mathrm{kHz}$ PWM of 25\% Duty Cycle.
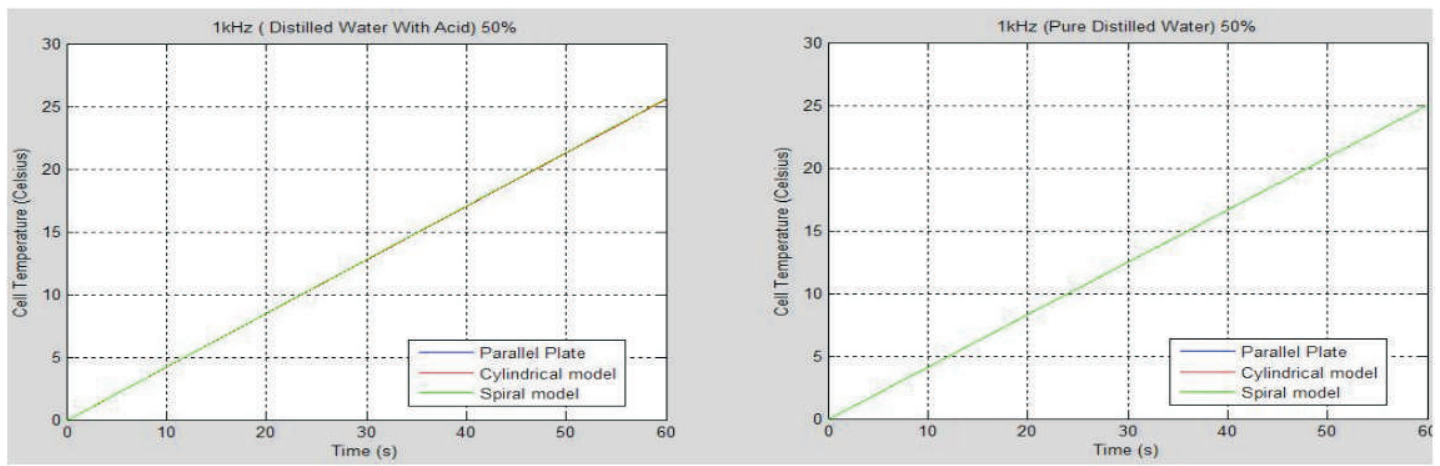

Fig. 24 : Cell Temperature with Respect to Time for 1kHz PWM of 50\% Duty Cycle.
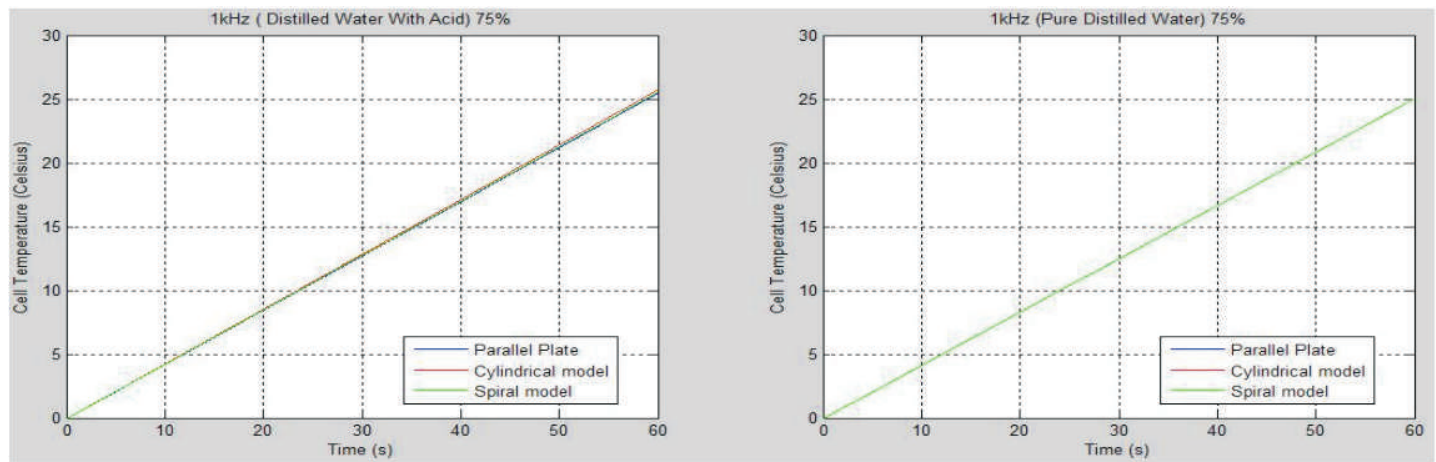

Fig. 25 : Cell Temperature with Respect to Time for $1 \mathrm{kHz}$ PWM of 75\% Duty Cycle. 

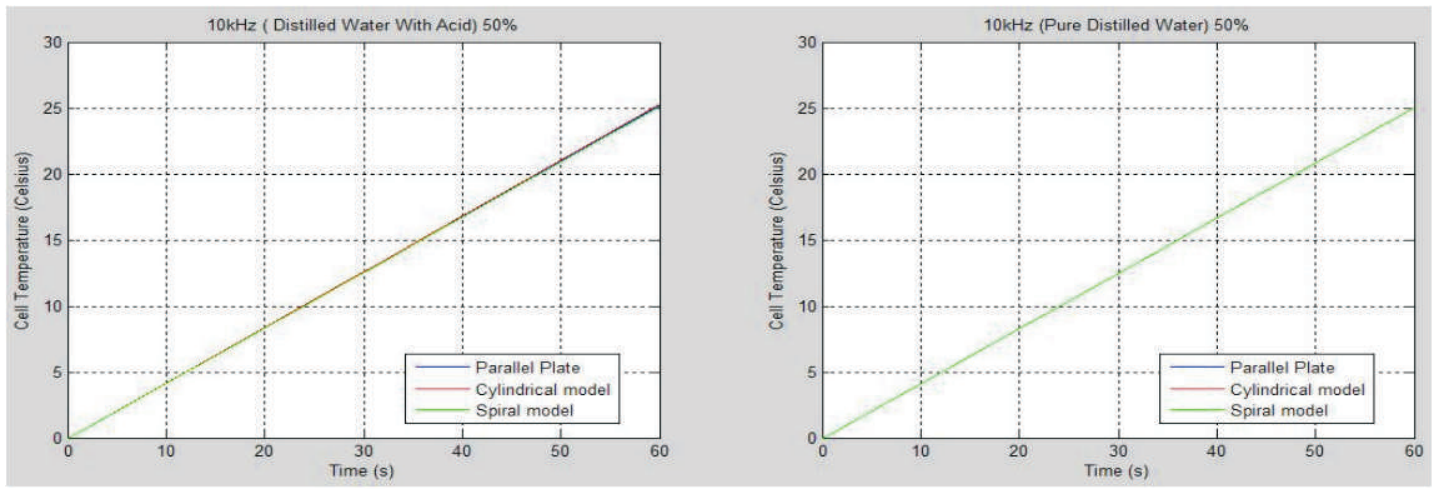

Fig. 26 : Cell Temperature with Respect to Time for 10kHz PWM of 50\% Duty Cycle.
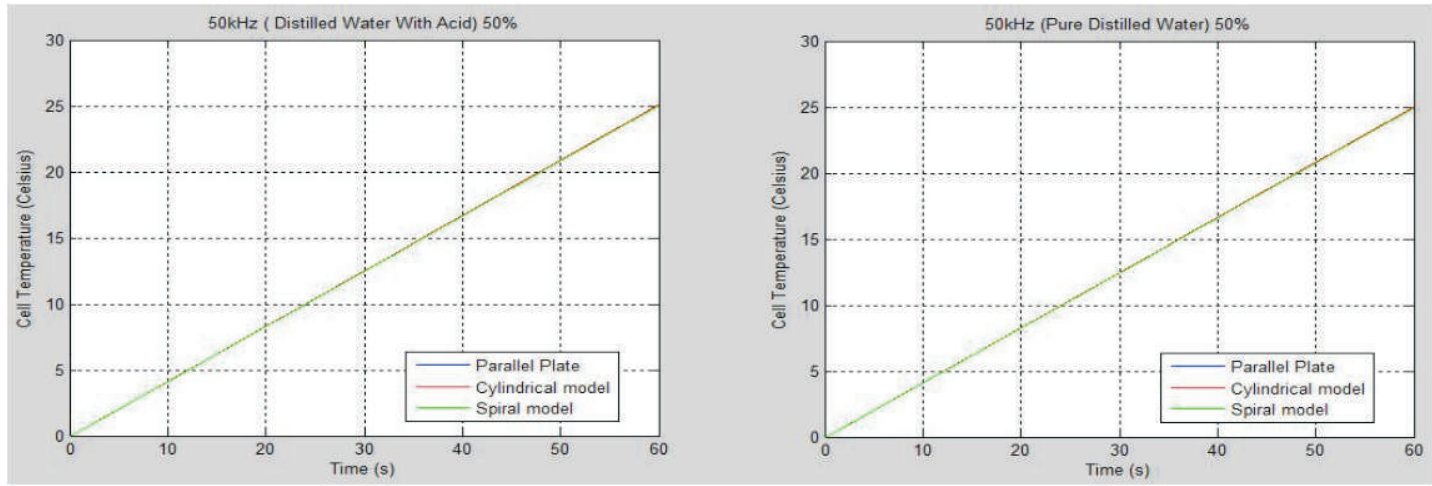

Fig. 27 : Cell Temperature with Respect to Time for 50kHz PWM of 50\% Duty Cycle.
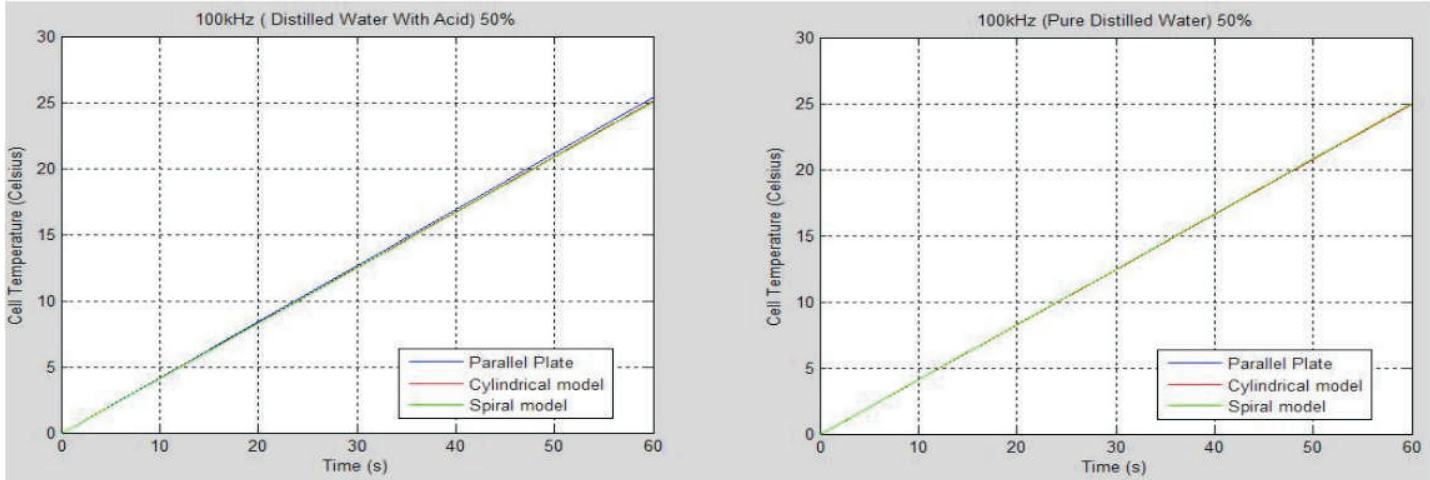

Fig. 28: Cell Temperature with Respect to Time for 100kHz PWM of 50\% Duty Cycle.

Finally, Fig..29(a) shows the practical setup for the experiment with the presence of light. Where it is investigated wither, there will be an effect of light on the electrolysis process or not. This experiment is to investigate if there is an effect from the light on the amount of HHO released, but through the experiment it has been noted that the more effect came from the temperature of the light. Fig.29(b) shows the volume of gas per energy and the cell temperature are the measurement target to investigate if there is an effect of the presence of light. The figure shows Volume of Gas per Energy and the cell temperature for three runs. The first two have been done at the same initial temperature $31^{\circ}$, one of them with light and the second without light, where the third one was without light and it started at $23.81^{\circ}$. It has been noticed that for the high temperature experiments the $\mathrm{HHO}$ released are more than the low temperature. 

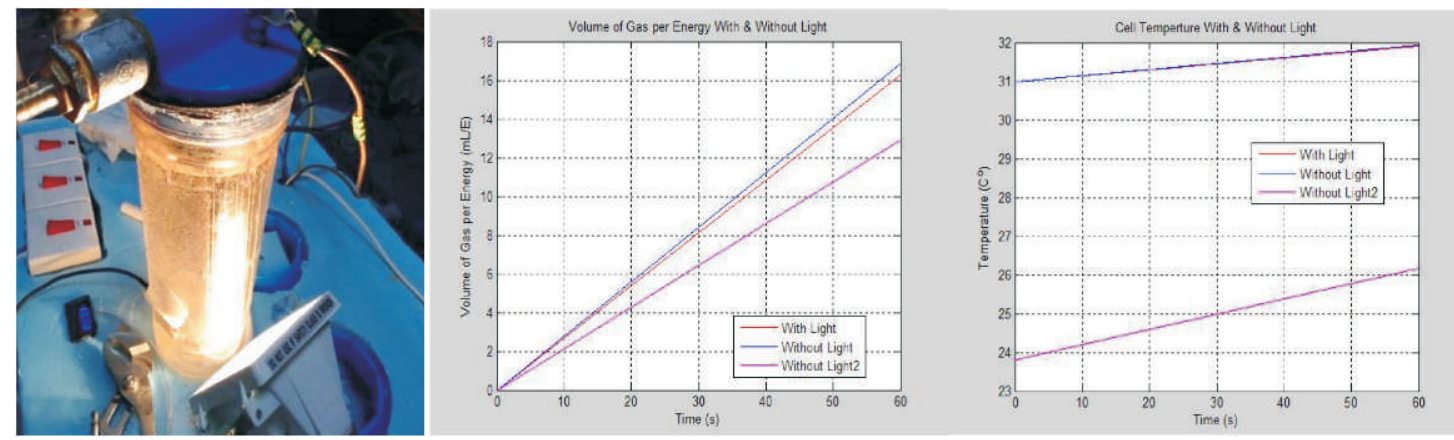

Fig. 29 : (a) Light Experiment Setup (b) DC voltage is supplied to the parallel plate model for investigation.

\section{Conclusion and Remarks}

In this paper, the photovoltaic system is considered as the renewable energy source and $\mathrm{HHO}$ cell is sub-system replacement for the energy storage system batteries. HHO cells have overcome many of the batteries' problems such as environment impact, reliability, pollution, cost and feasibility. Thus, three design alternatives have been proposed for the internal plates (Parallel, Cylindrical, Spiral) each of which can be modeled into electric circuit to calculate the plates parameters i.e. resistance, inductance and capacitance. Accordingly, this work can be extended to cover up the mathematical modeling and comparison to determine the optimum design in addition to the hardware design implementation as well as the design benchmarking and evaluations.In term of design safety, several actions have been proposed to insure the safety of the system. To isolate the produced gas from the system a bubbler has been suggested for isolation. In order to maintain fixed water level, an electric valve controlled by sensors on the water container will be installed. Moreover, a plexiglass box will be used to contain the system as a precaution for any further action. Finally, hydrogen sensor will be installed to detect hydrogen gas leakage. The complete design cost practically 1200 USD which means reduced the expected cost by $26 \%$.

\section{References}

[1]. BP World Wide, "Statistical Review of World Energy”, Workbook (xlsx), London, 2016.

[2]. Godfrey Boyle, "Renewable Energy", Oxford University Press, May 2004.

[3]. A. A. Lanjewar, et. al., "Design of HHO Cell Kit", International Journal of Chemical Sciences and Research (IJCSR), vol (7), pages 1-8, 2017.

[4]. M. Streblau, et. al., "The Influence of the Electrolyte Parameters on the Efficiency of the Oxyhydrogen (HHO) Generator", 2014 18th International Symposium on Electrical Apparatus and Technologies (SIELA), IEEE Conference, 2014, pp. 1-4.

[5]. R. M. Ahmed, et. al., "Off-Grid Diesel Generators Enhanced Performance using Photovoltaic
Powered On-Board HHO Generation: Experimental Validation", 2017 IEEE Second International Conference on DC Microgrids (ICDCM), IEEE Conference, 2017, pp.428-433.

[6]. K.P. Kumar; et. al., "Development of constant current power system for HHO cell operations to reduce fuel consumption", 2016 IEEE International Power Electronics and Motion Control Conference (PEMC), IEEE Conferences, 2016, pp. 273-279.

[7]. E. G. C. Vargas, "Design and implementation of a fuzzy controller which intervenes EFI system in a vehicle, for use HHO as a supplementary fuel", 2015 IEEE Thirty Fifth Central American And Panama Convention (Concapan Xxxv), IEEE Conference, 2015, pp.1-7.

[8]. Y. M. Shashikant and S. S. Maruti, "Parametric study on Oxy hydrogen gas generation and associated energy consumption using Taguchi's design of experiment concept," 2017 International Conference on Nascent Technologies in Engineering (ICNTE), Navi Mumbai, 2017, pp. 19.

[9]. M. M. EL-Kassaby, et. al., "Effect of hydroxy (HHO) gas addition on gasoline engine performance and emissions", Alexandria Engineering Journal (2016) 55, 243-251.

[10]. A. A. Al-Rousan, "Reduction of fuel consumption in gasoline engines by introducing HHO gas into intake manifold", International Journal of hydrogen energy, vol. 35, 1293 - 2935, 2010.

[11]. A.C. Yilmaz, et. al., "Effect of hydroxy (HHO) gas addition on performance and exhaust emissions in compression ignition engines", International Journal of hydrogen energy, vol. 35,2010.

[12]. British Stainless-Steel Association, "Making the Most of Stainless Steel", Dec.30,2014.

[13]. Battery University, www.batteryuniversity.com, Dec.30, 2014.

[14] AK Steel Corporation West Chester, OH 45069, Product data sheet 304/304L Stainless steel, UNS S30400/UNS S30403, http://www.aksteel.com/. 